Earth Interactions - Volume 16 (2012) • Paper No. 13 • Page 1

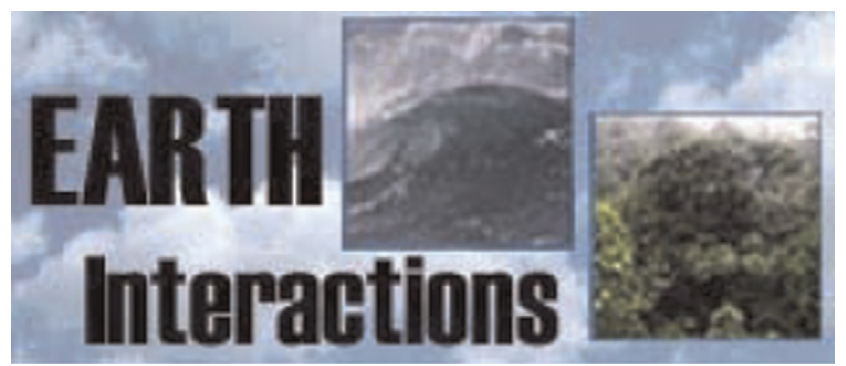

Copyright $\odot$ 2012, Paper 16-013; 55087 words, 3 Figures, 0 Animations, 3 Tables. http://EarthInteractions.org

\title{
Stream Discharge in Tropical Headwater Catchments as a Result of Forest Clearing and Soil Degradation
}

\section{John W. Recha and Johannes Lehmann*}

Department of Crop and Soil Sciences, Cornell University, Ithaca, New York

\section{Todd Walter}

Department of Biological and Environmental Engineering, Cornell University, Ithaca, New York

\section{Alice Pell}

Department of Animal Sciences, Cornell University, Ithaca, New York

\section{Louis Verchot}

Center for International Forestry Research, Bogor, Indonesia

\section{Mark Johnson}

Institute for Resources, Environment and Sustainability, and Department of Earth and Ocean Sciences, University of British Columbia, Vancouver, British Columbia, Canada

Received 23 January 2012; accepted 19 July 2012

* Corresponding author address: Johannes Lehmann, Department of Crop and Soil Sciences, 909 Bradfield Hall, Cornell University, Ithaca, NY 14853.

E-mail address: c1273@cornell.edu 
Earth Interactions - Volume 16 (2012) • Paper No. 13 • Page 2

\begin{abstract}
Tropical Africa is affected by intense land-use change, particularly forest conversion to agricultural land. In this study, the stream discharge of four small headwater catchments located within an area of $6 \mathrm{~km}^{2}$ in western Kenya was examined for 2 years (2007 and 2008). The four catchments cover a degradation gradient ranging from intact forest to agricultural land under maize cultivation for 5, 10, and 50 years. The runoff ratio (e.g., annual catchment discharge expressed as a percentage of rainfall) increased with increasing duration of cultivation from an average of $16.0 \%$ in the forest to $32.4 \%$ in the 50-yr-old agricultural catchment. Similarly, the average runoff ratio due to the stormflow component was 0.033 in the forest and increased gradually to 0.095 with increasing duration of cultivation. The conversion from forest to agricultural land in the first 5 years caused about half of the total observed increases in runoff ratio $(46.3 \%)$ and discharge in relation to rainfall $(50.6 \%)$. The other half of the changes in discharge occurred later during soil degradation after forest clearing. With increasing duration of cultivation, soil bulk density $\rho_{b}$ at a depth of $0-0.1 \mathrm{~m}$ increased by $46 \%$, while soil organic carbon (SOC) concentrations and total porosity decreased by $75 \%$ and $20 \%$, respectively. The changes in hydrological responses that occurred in the initial years after forest clearing may suggest a significant potential for improved land management in alleviating runoff and enhanced storm flow and moisture retention in agricultural watersheds.
\end{abstract}

KEYWORDS: Watershed; Deforestation; Soil degradation; Runoff; Erosion

\title{
1. Introduction
}

Land use is one of the key parameters controlling fluxes in the hydrologic cycle. Removal of forest cover typically results in a considerable increase in water yield (Bosch and Hewlett 1982; Farley et al. 2005) with significant effects on stream water quality, soil erosion, and losses of nutrients (Grip et al. 2004). The impact of land-use change on hydrologic processes in the tropics is particularly severe since soil degradation is more rapid than in temperate zones because of more rapid mineralization of soil organic matter (SOM) and often high erosion where the topography is steep and rainfall intensities are high (Spaans et al. 1989; Malmer and Grip 1990; Hartemink et al. 2008; Solomon et al. 2009). Changes in watershed dynamics in response to deforestation in the humid tropics were widely investigated during the 1980s (Bruijnzeel 1990; Bonell and Balek 1993), but less work has been done recently. Most of the earlier studies focused on catchments in tropical Asia or Central and South America. Limited results from West Africa show that forest clearing and subsequent land use significantly affect the magnitude of runoff and erosion using plot studies (Lal 1981). Yet there are few studies on stream water discharge, runoff partitioning, and their relation to land-use change, particularly for East Africa, where forest pressures continue to be acute because of a rural population density that is among the highest in the world (Kenya Forest Service 2007).

Forest removal is a major factor increasing total stream water discharge and the proportion of discharge occurring as storm runoff (Mumeka 1986). In humid regions, the forest vegetation transpires water throughout the entire year (Calder 1998), whereas in agricultural landscapes annual crops consume water only during the growing season. In addition, the larger plant litter input and root turnover in forests compared to cropped fields maintain greater soil organic carbon (SOC) 
Earth Interactions - Volume 16 (2012) • Paper No. 13 • Page 3

concentrations, which in turn preserves soil structure and promotes higher infiltration capacities, lower Hortonian overland flow, and greater water storage capacity (Fritsch 1993). With continued cultivation over a period of years, particularly in low-input and subsistence systems, soils begin to lose SOC and become compacted, which has profound effects on soil hydrology (Giertz and Diekkruger 2003; Awiti et al. 2008). Particularly in the tropics, SOC losses can be rapid (Solomon et al. 2007). It is, therefore, especially likely that for tropical agricultural landscapes, soil degradation, in addition to the loss of forest cover, has important impacts on stream water discharge.

The aim of this study was to quantify the effects of forest conversion to continuous cultivation on the stream discharge of headwater catchments in tropical Africa. The effects of cultivation on water yield were investigated for a chronosequence of four catchments in western Kenya composed of a forested headwater catchment and three headwater catchments under continuous maize production for 5,10 , and 50 years following forest conversion.

\section{Methods}

\section{1 The study site}

The field measurements were done in Kapchorwa, located in the Nandi district in western Kenya (Figure 1). The site is located $60 \mathrm{~km}$ northeast of Lake Victoria at latitude $0^{\circ} 10^{\prime} 0^{\prime \prime} \mathrm{N}$ and longitude $35^{\circ} 0^{\prime} 0^{\prime \prime} \mathrm{E}$. The region belongs to the subhumid ecological zone characterized by a bimodal rainy season with a mean annual precipitation of $2000 \mathrm{~mm}$ (Haupt 2000). The "long rain season" is from April to June $(\sim 1200 \mathrm{~mm})$ and the "short rain season" is from August to October $(\sim 800 \mathrm{~mm})$. The site has an elevation of 1750-1900 $\mathrm{m}$ above mean sea level, an average maximum daily temperature of $26^{\circ} \mathrm{C}$, and an average minimum of $11^{\circ} \mathrm{C}$ (Glenday 2006).

The Kakamega-Nandi forest in western Kenya is the country's only remaining tropical rain forest. Total forest cover in Kenya decreased by $0.3 \% \mathrm{yr}^{-1}$ on average between 1990 and 2005, to $35220 \mathrm{~km}^{2}$, which represents $6 \%$ of the country's territory according to the Global Forest Resources Assessment (FAO 2010). The forest forms the easternmost relic of the Guinean-Congolian rain forest belt, which once spanned from East to West Africa. The area around this forest is among the most densely populated rural areas in the world. It had a population density of 578 persons per square kilometer in 1999 (Muller and Mburu 2009), compared to 54 persons per square kilometer for the entire country (World Bank 2008). Consequently, the forest is under high anthropogenic pressure, which is mirrored by the decreasing natural forest cover and intensive cultivation (deGraffenried and Shepherd 2009; Swallow et al. 2009). Past deforestation rates in the Kakamega-Nandi forest indicated a decrease of forest area and an increase in the fragmentation of natural, old-growth forest (Mitchell 2004; Lung and Schaab 2006).

Soils in the Kapchorwa catchment are kaolinitic acrisols (FAO-UNESCO-ISRIC 1988), which are classified as ultisols in the U.S. soil taxonomy (U.S. Natural Resources Conservation Service 2003). The parent material of these soils is principally granitic, with some inclusions of Precambrian gneisses, which supports 


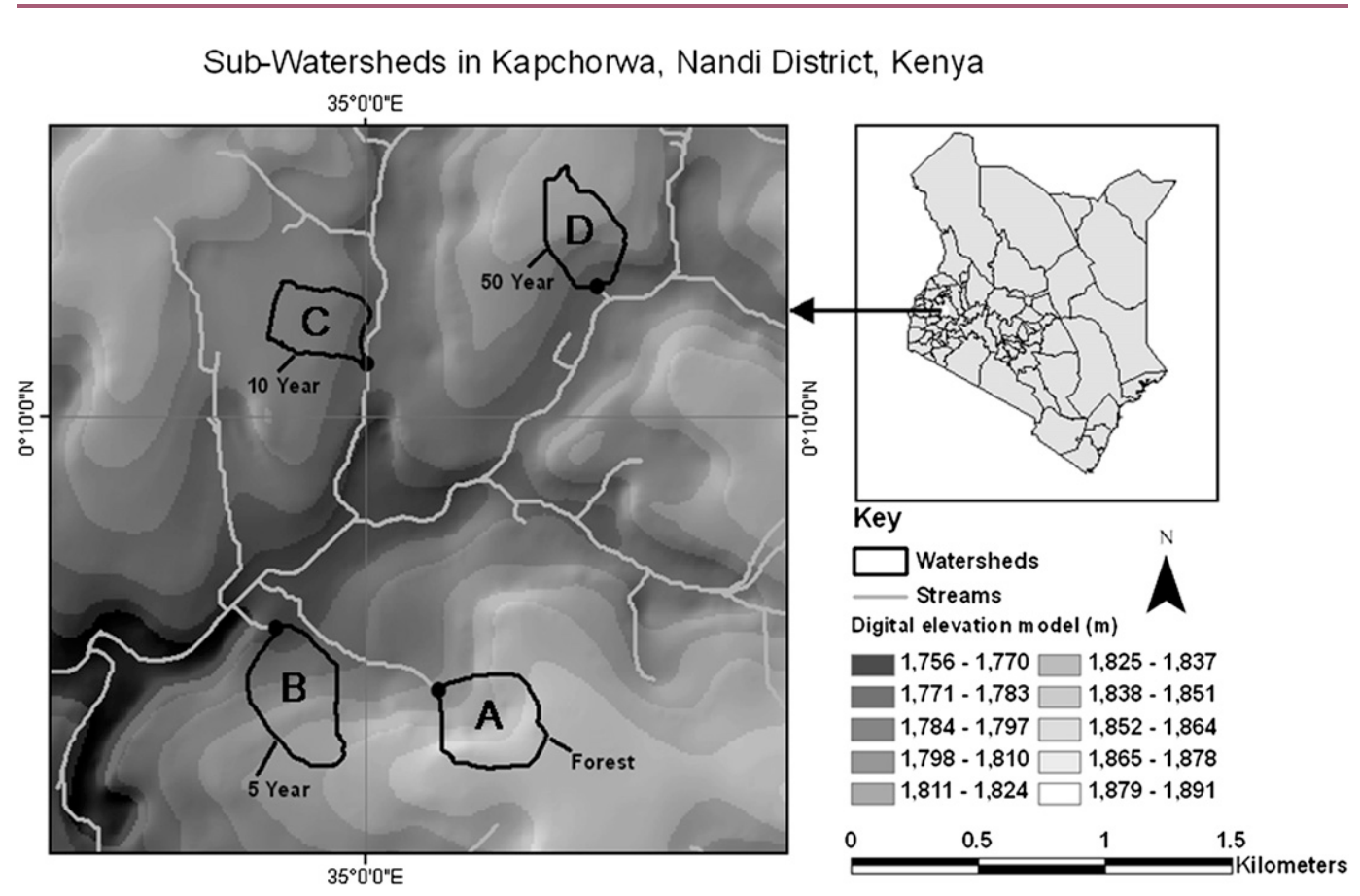

Figure 1. Map of the study area of the Kapchorwa headwater chronosequence of catchments in western Kenya and its approximate location within Kenya (inset shows Kenya and its districts). The weir positions are shown by dots in each catchment. Letters indicate land-use histories of the catchments: (a) forested catchment and maize cultivation for (b) 5 , (c) 10, and (d) 50 years following forest conversion.

luvisols (Werner et al. 2007) and other undifferentiated basement system rocks at higher elevations (Jätzold and Schmidt 1983). Soils in the study area have 45\%-49\% clay, $15 \%-25 \%$ silt, and 26\%-40\% sand (Kimetu et al. 2008).

The forest section of the Kapchorwa catchment is part of the Kakamega-Nandi forest composed of tropical rain forest species. It is largely an indigenous forest with a 30-m closed canopy dominated by evergreen hardwood species. The most common species are Funtumia africana, Ficus species, Croton species, and Celtis species (Glenday 2006). Other species include Aningeria altissima (A. Chev.), Milicia excelsa (Welw.) C.C. Berg, Antiaris toxicaria (Lesch) and Chrysophyllum albidum (G. Don), Olea capensis (L.), and Croton megalocarpus (Hutch) (Kinyangi 2008). The above and below ground net primary production of trees in a tropical forest is estimated at $15.2 \mathrm{Mg} \mathrm{ha}^{-1} \mathrm{yr}^{-1}$ (Hertel et al. 2009). The agricultural catchments have maize as the main crop with farm sizes of less than 1 ha and have been under maize cultivation since conversion from forest cover. Minor areas around the homesteads may include banana, coffee, and kitchen gardens. The soil is in most cases prepared by handheld hoes and only in some cases ox plows. The maize grain yield without fertilizer input in the 5-, 10-, and 50-yr-old agricultural catchments are 6.5, 5.5, and $2.5 \mathrm{Mg} \mathrm{ha}^{-1} \mathrm{yr}^{-1}$, respectively (Ngoze et al. 2008). 
Earth Interactions - Volume 16 (2012) • Paper No. 13 • Page 5

\subsection{Hydrologic instrumentation and field data collection}

The headwater catchments were initially characterized in August 2006. The specific age classes designating when native forests were converted to agriculture were determined from historical community settlement patterns over the last century (Bleher et al. 2006). Specific years of conversion were verified from records of the Kenyan government from the Department of Forests, the Ministry of Agriculture, as well as from interviews with officials of local institutions and from county council records. Within each site, there were distinct population settlement patterns where newly acquired fields were excised from sections of the native forest for agriculture. All four headwater catchments are located within an area of $6 \mathrm{~km}^{2}$ and represent a soil degradation gradient that corresponds to years under maize cultivation that has been used and its validity verified by several other studies (Solomon et al. 2007; Kimetu et al. 2008; Kimetu et al. 2009; Ngoze et al. 2008). Such chronosequences substitute time for space and have to be carefully selected to ensure similar properties before the change (Huggett 1998). Also hydrological differences between catchments unrelated to land cover have to be considered (Elsenbeer 2001; Johnson et al. 2006). Therefore, the relationship between hydrological responses and physical watershed attributes such as size and slope as well as location characteristics such as rainfall were investigated as a source of random variation. Because of lack of replication, comparisons between individual watersheds should be viewed with caution and rather global trends across all four watersheds be interpreted.

Hydrologic instrumentation was installed in mid-December 2006 and catchments monitored for 2 years. The boundaries of each catchment were surveyed and delineated using a global positioning system (GPS). The GPS data were then used to generate a geographical information system (GIS) output and map of the area. The sizes of the catchments were 12.8 ha for the forest, 14.4 ha for the 5-yr-old conversion, 9.1 ha for the $10-y r$ conversion, and 10.0 ha for the $50-y r$ conversion. A standard V-notch weir was constructed at each catchment outlet for determining stream discharge. The V-notch weirs had an angle of $60^{\circ}$, with an overall opening of $0.22 \mathrm{~m}^{2}$ and a capacity of greater than $200 \mathrm{~L} \mathrm{~min}^{-1}$ for a sharp-crested weir. They were located at a distance of 10-20 m from the spring. No overflow events were recorded. Stream stage was recorded using water level capacitance probes (Odyssey Dataflow Systems Pty Ltd., New Zealand) installed at the weir. The probes were programmed to give a reading of the average stream stage between 2 and $4 \mathrm{~min}$. Data from these probes were downloaded biweekly. The weir ratings were determined at low and intermediate flows using a stage downstream and discharge at the weir. The correlation coefficients of the weir ratings were $r^{2}=$ $0.944(y=0.5483 x-12.079), r^{2}=0.915(y=0.5495 x-18.286), r^{2}=0.926$ $(y=0.5329 x-16.382)$, and $r^{2}=0.931(y=0.8608 x-48.769)$ for the forest, 5-, $10-$, and 50-yr conversions, respectively. Failure in data acquisition occurred occasionally and missing values were linearly interpolated using the stage downstream and weir rating equations.

Precipitation was determined from a tipping-bucket rain gauge connected to a datalogger installed $1 \mathrm{~m}$ above the ground surface in the agricultural catchments, representing open-area rainfall (e.g., rain gauges installed above the maximum canopy height). For all calculations, an average of open-area precipitation was used 
Earth Interactions - Volume 16 (2012) • Paper No. 13 • Page 6
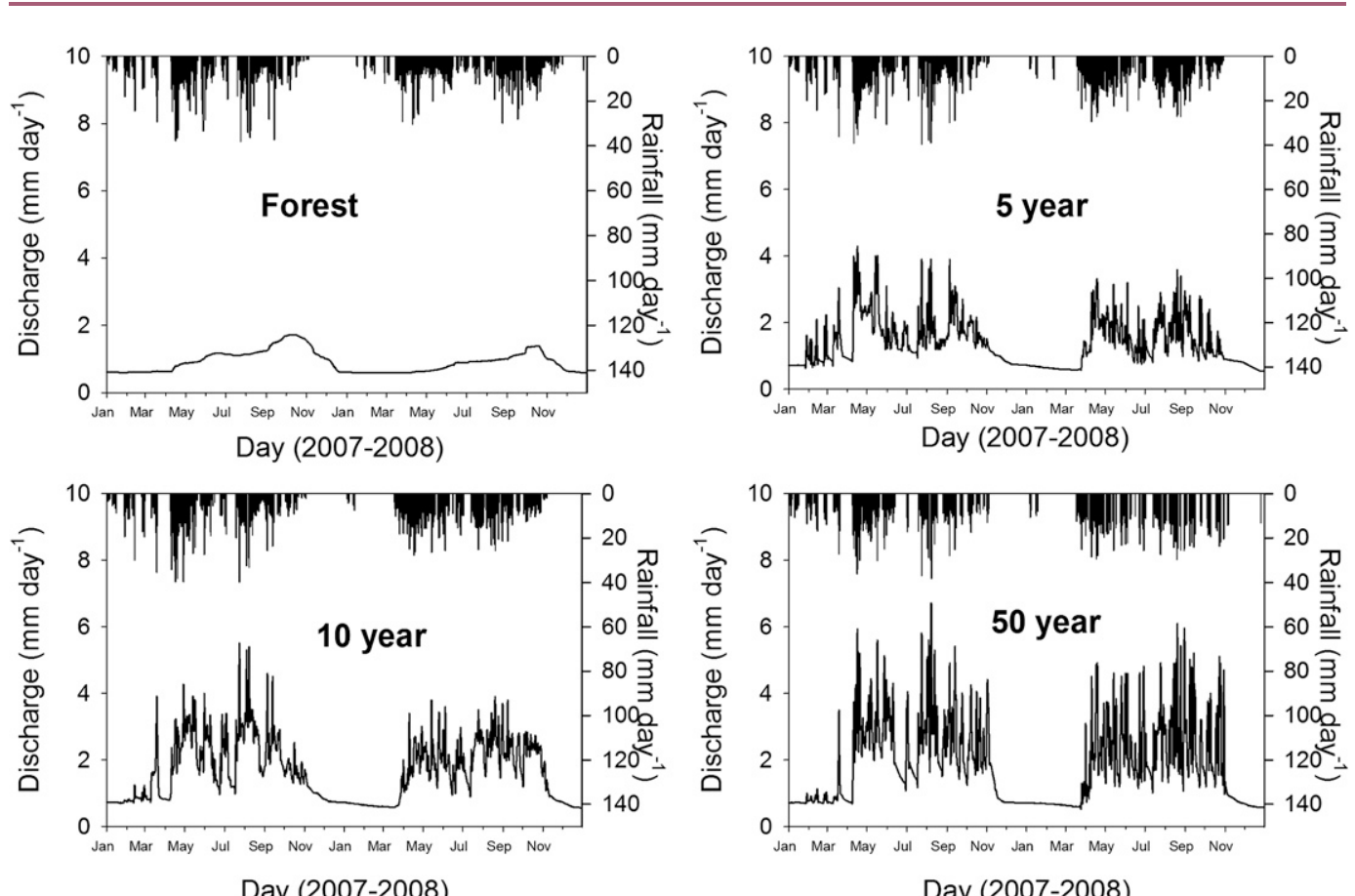

Figure 2. Daily discharge and rainfall of the Kapchorwa chronosequence of catchments in western Kenya in 2007 and 2008 for (a) forested and agricultural catchments with (b) 5 , (c) 10 , and (d) 50 years of cultivation.

[coefficient of variation (CV) of less than $1 \%$ between watersheds], but individual rain gauges are shown in Figure 2 (average for the forest).

Five soil samples from 0 - to $0.1-\mathrm{m}$ depth were collected randomly by stratifying for location within slope and plateau of each catchment, after carefully removing the litter layer (capturing only the mineral horizon). The average slopes for the headwater catchments were measured using clinometers. The final average slope figure is a mean of five readings taken from the position of the weir up the slope. The resulting mean slopes for the catchments were $7.5 \%$ for the forest, $6.4 \%$ for the 5 -yr conversion, $4.4 \%$ for the 10 -yr conversion, and $5.8 \%$ for the 50 -yr conversion. Bulk density was determined from undisturbed soil cores; we used five soil samples from a depth of 0-0.1 $\mathrm{m}$ in each catchment (Campbell and Henshall 1991). The soil porosity $\phi$ was computed from bulk density $\rho_{b}$ and particle density $\rho_{p}$ using the formula $\phi=1-\left(\rho_{b} / \rho_{p}\right)$.

\subsection{Hydrological analysis}

The stream hydrographs were normalized by corresponding catchment sizes to allow comparisons across the four catchments. The runoff ratio RR was computed for each catchment as the ratio of the total annual runoff to total rainfall (e.g., Berger and Entekhabi 2001). Streamflow data were further analyzed using hydrograph separation implemented in the Web GIS-based Hydrograph Analysis Tool 
Earth Interactions - Volume 16 (2012) • Paper No. 13 • Page 7

(WHAT) using the recursive digital filter method for baseflow separation (Lim et al. 2005; Lim et al. 2010). This approach to hydrograph separation has been used in hydrological studies of forested and agricultural watersheds in tropical and temperate regions (Longobardi and Villani 2008; Schwartz 2007). Two other separation techniques, specifically the WHAT local minimum method and the WHAT one parameter digital filter method (Lim et al. 2005), were used for comparison. The trends in the amount of baseflow and runoff were similar for all the methods, with a variation of up to $12.8 \%$ in the final results. Hydrologic parameters determined from the hydrograph separation include the baseflow and stormflow components of the runoff ratio $\left(\mathrm{RR}_{\mathrm{BF}}\right.$ and $\mathrm{RR}_{\mathrm{SF}}$ as the ratio of total baseflow and stormflow to total rainfall, respectively). We also evaluated the baseflow index (BFI) as the ratio of baseflow to total discharge (Bloomfield et al. 2009). Cumulative flow duration curves (on a probability axis) were calculated to compare the differences in high, low, and median flows across the watersheds (Vogel and Fennessey 1994). The flashiness of the water sheds was compared using the flashiness index method of Baker et al. (Baker et al. 2004).

\subsection{Laboratory measurements of soil properties and statistical analysis}

Total $\mathrm{C}$ was determined by dry combustion after fine grinding soil using a Mixer Mill (MM301, Retsch, Germany). The five replicate samples were analyzed for total $\mathrm{C}$ with a CN analyzer (ANCA-GSL, PDZ Europa Ltd., Sandbach, United Kingdom) and considered as SOC since no carbonates are expected at $\mathrm{pH}$ values at and below 6 as found at these sites (Kimetu et al. 2008). SOM was determined by loss on ignition (Storer 1984). The soil moisture retention curve was determined by applying soil suction to undisturbed soil cores (Klute 1986).

Statistical analyses were done using JMP version 8 (SAS Institute Inc., Cary, North Carolina) for soil properties and hydrological parameters for the four catchments. The comparisons were considered statistically significant at $P<0.05$ unless otherwise stated. A linear function was fitted for all the correlations.

\section{Resullts}

The SOC concentrations in the topsoil (to $0.1 \mathrm{~m}$ ) of the watersheds ranged from 28 to $108 \mathrm{mg} \mathrm{g}^{-1}$, and bulk densities ranged from 1.2 to $0.8 \mathrm{~g} \mathrm{~cm}^{-3}$, depending on the conversion age (Table 1). Porosity decreased from 0.70 to 0.56 and field capacity (at 0.33 bar) decreased from $35 \%$ to $23 \%$ during land-use conversion and long-term cultivation. There was no clear separation between the long rainy (AprilJune) and short rainy (August-October) seasons in the Kapchorwa catchment area during the study period (Figure 2). Truly dry seasons occurred between November and March.

The streamflow response to precipitation events varied with land-use history (Figure 2). Unlike the flashy streamflow responses for catchments under cultivation, the discharge in the forest did not respond immediately to the rainfall. There was minimal storm runoff for the forest and a gradual increase in the streamflow discharge in the forest during the rainy season that reached its peak in October. The 
Earth Interactions - Volume 16 (2012) - Paper No. 13 • Page 8

Table 1. Soil properties in the top $0.1 \mathrm{~m}$ for the Kapchorwa headwater chronosequence of catchments in western Kenya. Means within a row followed by the same letters are not significantly different from each other at $P<0.05(n=5)$.

\begin{tabular}{lcccc}
\hline & Forest & $\begin{array}{c}5-\mathrm{yr} \\
\text { conversion }\end{array}$ & $\begin{array}{c}10-\mathrm{yr} \\
\text { conversion }\end{array}$ & $\begin{array}{c}50-\mathrm{yr} \\
\text { conversion }\end{array}$ \\
\hline Soil organic matter $\left(\mathrm{mg} \mathrm{g}^{-1}\right)$ & $170.8 \mathrm{a}$ & $136.7 \mathrm{~b}$ & $85.3 \mathrm{c}$ & $70.0 \mathrm{~d}$ \\
Soil organic carbon $\left(\mathrm{mg} \mathrm{g}^{-1}\right)$ & $108.3 \mathrm{a}$ & $68.8 \mathrm{~b}$ & $36.4 \mathrm{c}$ & $27.5 \mathrm{c}$ \\
Soil bulk density $\left(\mathrm{g} \mathrm{cm}^{-3}\right)$ & $0.80 \mathrm{c}$ & $0.91 \mathrm{~b}$ & $1.03 \mathrm{ab}$ & $1.17 \mathrm{a}$ \\
Total porosity & $0.70 \mathrm{a}$ & $0.66 \mathrm{~b}$ & $0.61 \mathrm{bc}$ & $0.56 \mathrm{c}$ \\
Moisture at 0.1 bar (\%) & $48.09 \mathrm{a}$ & $43.71 \mathrm{a}$ & $38.97 \mathrm{~b}$ & $31.72 \mathrm{c}$ \\
Moisture at 0.33 bar (field capacity) (\%) & $34.70 \mathrm{a}$ & $34.05 \mathrm{a}$ & $24.88 \mathrm{~b}$ & $22.97 \mathrm{~b}$ \\
Moisture at 1 bar (\%) & $33.44 \mathrm{a}$ & $32.95 \mathrm{a}$ & $23.33 \mathrm{~b}$ & $21.89 \mathrm{~b}$ \\
Moisture at 3 bar $(\%)$ & $31.89 \mathrm{a}$ & $29.56 \mathrm{a}$ & $20.07 \mathrm{~b}$ & $18.71 \mathrm{c}$ \\
Moisture at 15 bar (permanent wilting point) $(\%)$ & $30.27 \mathrm{a}$ & $27.78 \mathrm{~b}$ & $17.18 \mathrm{c}$ & $15.54 \mathrm{c}$ \\
\hline
\end{tabular}

initial rainfall in April 2007 and 2008 following the usual dry season did not lead to sudden increased discharge in agricultural catchments. After about 1 month of rainfall, the streamflow exhibited periods of slowly increased discharge in the agricultural catchments associated with rainfall.

The annual water yield of the catchments (expressed as specific discharge and as RR; Table 2) indicates a pronounced increase between forest and 5 years of cultivation, followed by a gradual increase in the streamwater discharge with longer periods of cultivation. The RR for 2007 (e.g., total streamwater yield in relation to the precipitation) was $17.9 \%$ in the forest, $26.6 \%$ in the $5-\mathrm{yr}, 30.3 \%$ in the $10-\mathrm{yr}$, and $34 \%$ in the 50-yr conversion to agriculture. The annual RR for 2008 in relation to the precipitation was $14.1 \%$ in the forest, $22.0 \%$ in the $5-\mathrm{yr}, 27.4 \%$ in the $10-\mathrm{yr}$, and $30.7 \%$ in the 50 -yr conversions. About half of the change $(50.6 \%)$ in discharge as a fraction of rainfall occurred over the first 5 years of cultivation after forest clearing, with the remaining increase over the chronosequence $(49.4 \%)$ observed for 5-50 years of cultivation. This was consistent across the $\mathrm{RR}_{\mathrm{SF}}, \mathrm{RR}_{\mathrm{BF}}$, and $\mathrm{BFI}$ hydrologic parameters (Table 2). The stormflow component of the runoff ratio

Table 2. The hydrological attributes of the Kapchorwa headwater chronosequence of catchments in western Kenya in 2007 and 2008. Annual precipitation was 2064.7 and $2099.7 \mathrm{~mm}$ for 2007 and 2008, respectively.

\begin{tabular}{|c|c|c|c|c|c|c|c|c|}
\hline & \multicolumn{2}{|c|}{ Forest } & \multicolumn{2}{|c|}{ 5-yr conversion } & \multicolumn{2}{|c|}{ 10-yr conversion } & \multicolumn{2}{|c|}{ 50-yr conversion } \\
\hline & 2007 & 2008 & 2007 & 2008 & 2007 & 2008 & 2007 & 2008 \\
\hline Discharge (mm) & 370 & 296 & 549 & 462 & 637 & 574 & 702 & 645 \\
\hline $\mathrm{RR}^{\mathrm{a}}$ & 0.18 & 0.14 & 0.27 & 0.22 & 0.30 & 0.27 & 0.34 & 0.31 \\
\hline Stormflow (mm) & 77 & 61 & 131 & 123 & 163 & 150 & 189 & 203 \\
\hline $\mathrm{RR}_{\mathrm{SF}}{ }^{\mathrm{b}}$ & 0.037 & 0.029 & 0.064 & 0.059 & 0.079 & 0.072 & 0.092 & 0.097 \\
\hline Base flow (mm) & 293 & 235 & 417 & 339 & 474 & 424 & 513 & 442 \\
\hline $\mathrm{RR}_{\mathrm{BF}}^{\mathrm{c}}$ & 0.14 & 0.11 & 0.20 & 0.16 & 0.23 & 0.20 & 0.25 & 0.21 \\
\hline $\mathrm{BFI}^{\mathrm{d}}$ & 0.79 & 0.79 & 0.76 & 0.73 & 0.74 & 0.74 & 0.73 & 0.69 \\
\hline Flashiness index & 0.007 & 0.005 & 0.17 & 0.20 & 0.16 & 0.15 & 0.23 & 0.31 \\
\hline
\end{tabular}

\footnotetext{
a Total annual discharge/precipitation.

${ }^{\mathrm{b}}$ Stormflow/precipitation.

${ }^{\mathrm{c}}$ Baseflow/precipitation.

${ }^{\mathrm{d}}$ Baseflow/total discharge.
} 


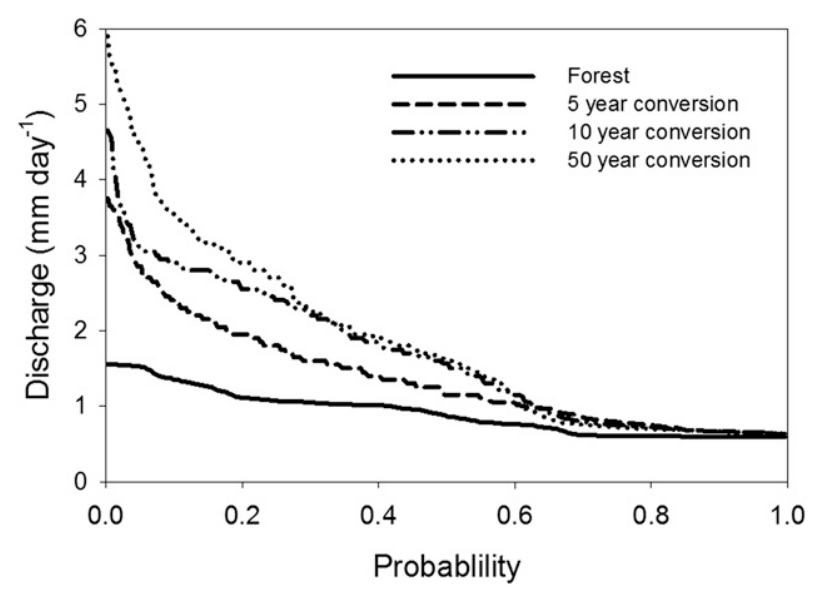

Figure 3. Cumulative flow duration curves of the Kapchorwa headwater chronosequence of catchments (average of 2007 and 2008).

$\mathrm{RR}_{\mathrm{SF}}$ for the forested catchment increased from 0.033 and 0.029 to 0.092 and 0.097 after 50 years of cultivation (2007 and 2008 data, respectively). Slightly less than half of the change $(46.3 \%)$ was observed within the first 5 years of cultivation (0.064 and 0.059 for 2007 and 2008, respectively). On average for both years, BFI decreased by $11 \%$ over 50 years of continuous agriculture following forest clearing. Slightly less than half $(45 \%)$ of that decrease occurred after forest clearing and within the first 5 years of cultivation. On average for both years, the flashiness index after forest conversion was 30 times higher after 5 years of cultivation and 45 times higher after 50 years of cultivation (Table 2). The flow duration analysis followed the pattern of the runoff ratio (Figure 3). The 10-yr curve evolves toward the 50-yr curve for high-frequency flows and matches the 5 -yr curve for low-frequency flows (i.e., high flows).

Streamwater discharge as a percentage of rainfall and the runoff ratio were inversely related to SOC $(P<0.01)$ and total porosity $(P<0.05)$ and positively correlated to $\rho_{b}(P<0.05$; Table 3$)$. Conversely, BFI had a significant inverse relationship with $\rho_{b}(P<0.05)$ and a positive correlation with total porosity $(P<$ 0.05 ) but was not significantly correlated with SOC. There were no significant relationships between the three aforementioned hydrological properties and either the average slope or catchment size $(P>0.05)$ that would indicate a bias in watershed responses due to random spatial effects.

\section{Discussion}

\subsection{Changes in soil properties}

The changes in SOC and soil physical properties were in agreement with previous studies on over 100 farm fields in the same region (Kimetu et al. 2008; Kinyangi 2008) of which these watersheds represent a subset. Measured porosity and field capacity correspond to changes in available water capacity noted by 
Earth Interactions - Volume 16 (2012) • Paper No. 13 • Page 10

Table 3. Correlation coefficients $\left(r^{2}\right)$ and regression equations for some physical and hydrological attributes averaged for both 2007 and 2008 of the Kapchorwa headwater catchments.

\begin{tabular}{|c|c|c|c|}
\hline & $\begin{array}{c}\text { Discharge as a percentage } \\
\text { of rainfall }\end{array}$ & Runoff ratio & Baseflow index \\
\hline Soil organic carbon $(\%)$ & $\begin{aligned} y & =-1.92 x+37.0 \\
r^{2} & =0.987 *\end{aligned}$ & $\begin{aligned} y & =-0.007 x+0.109 \\
r^{2} & =0.958 *\end{aligned}$ & $\begin{aligned} y & =0.0096 x+0.693 \\
r^{2} & =0.896^{* *}\end{aligned}$ \\
\hline Bulk density $\left(\mathrm{g} \mathrm{cm}^{-3}\right)$ & $\begin{aligned} y & =43.2-14.5 \\
r^{2} & =0.937 *\end{aligned}$ & $\begin{aligned} y & =0.161 x-0.091 \\
r^{2} & =0.965^{*}\end{aligned}$ & $\begin{aligned} y & =-0.212 x+0.954 \\
r^{2} & =0.925^{*}\end{aligned}$ \\
\hline Total porosity & $\begin{aligned} y & =-113 x+96.9 \\
r^{2} & =0.937^{*}\end{aligned}$ & $\begin{aligned} y & =-0.421 x+0.333 \\
r^{2} & =0.961 *\end{aligned}$ & $\begin{aligned} y & =0.550 x+0.399 \\
r^{2} & =0.913^{*}\end{aligned}$ \\
\hline $\begin{array}{l}\text { Soil moisture content } \\
\text { at field capacity }(\%)\end{array}$ & $\begin{aligned} y & =-1.04 x+55.7 \\
r^{2} & =0.799 * *\end{aligned}$ & $\begin{aligned} y & =-0.0038 x+0.178 \\
r^{2} & =0.793^{* *}\end{aligned}$ & $\begin{aligned} y & =0.0047 x+0.609 \\
r^{2} & =0.679^{* *}\end{aligned}$ \\
\hline Average slope $(\%)$ & $\begin{aligned} y & =-4.30 x+51.3 \\
r^{2} & =0.614 * *\end{aligned}$ & $\begin{aligned} y & =-0.015 x+0.155 \\
r^{2} & =0.520 * *\end{aligned}$ & $\begin{aligned} y & =0.017 x+0.643 \\
r^{2} & =0.409 * *\end{aligned}$ \\
\hline Catchment size (ha) & $\begin{aligned} y & =-1.90 x+47.4 \\
r^{2} & =0.431 * *\end{aligned}$ & $\begin{aligned} y & =0.0068 x+0.1447 \\
r^{2} & =0.403 * *\end{aligned}$ & $\begin{aligned} y & =0.0075 x+0.661 \\
r^{2} & =0.276^{* *}\end{aligned}$ \\
\hline
\end{tabular}

* Significant correlations at $P<0.05(n=4)$.

** Not significant at $P<0.05$.

Moebius-Clune et al. (Moebius-Clune et al. 2011) for 36 farms in the same region. Therefore, these watersheds are broadly representative of the studied region and corroborate more rigorously replicated plot studies. Qualitatively, the changes in soil hydraulic properties agree with a study by Price et al. (Price et al. 2010) in the United States, who found as much as $38 \%$ higher bulk densities and 7 times lower saturated hydraulic conductivity in lawn and pasture soils compared to forest soils.

\subsection{Effects of forest removal}

The conversion of forest to maize cultivation led to drastic changes of the vegetation cover that significantly affected the stream discharge and flashiness. The RR (discharge expressed as a percentage of the rainfall) increased by an average of $44.2 \%$ while flashiness increased 30 -fold from forest to the adjacent catchment after 5 years of maize cultivation (Table 2). This translates to an average increase of stream discharge by $34.4 \mathrm{~mm} \mathrm{yr}^{-1}(8.8 \%)$ and a sixfold increase in flashiness per year. Similar stream discharge values were reported from other conversion studies. Low and Goh (Low and Goh 1972), reporting on catchment research in peninsular Malaysia, showed an annual increase of $10 \%$ in water yield in a largely cleared catchment compared to yield trends in three forested catchments. A study by Ruprecht and Schofield (Ruprecht and Schofield 1989) in a catchment area of 94 ha showed that clearing native vegetation and establishment of agricultural plants on a small catchment in southwest Australia resulted in a large streamflow increase. The RR increased by $10 \%$ in the first year after clearing and continued to increase linearly at a slower rate of $3 \% \mathrm{yr}^{-1}$ for a further 6 years, when a new streamflow equilibrium was reached (Ruprecht and Schofield 1989).

The reduced water use of annual crops such as maize compared to a full-grown forest reflects not only the diminished capacity of short vegetation to intercept and evaporate rainfall (Van Dijk and Bruijnzeel 2001) but also its ability to extract 
water from deeper soil layers during periods of drought (Eeles 1979). The former relates primarily to the lower aerodynamic roughness of short annual crops (and possibly to their lower leaf area index), whereas the reduced water uptake of crops reflects their more limited rooting depth (Nepstad et al. 1994; Calder 1998). In the forest, rainfall reaching the soil (throughfall) may be reduced by interception to a greater extent than in maize fields. In the Cerrado region of Brazil, Lilienfein and Wilcke (Lilienfein and Wilcke 2004) reported interception losses of 11\%-24\% in maize fields and $16 \%-26 \%$ in a pine plantation but only less than $11 \%$ in native Cerrado vegetation. However, variability of throughfall and stemflow to estimate interception may be highly variable in space and time as seen for a palm-rich forest in Amazonia (Germer et al. 2006).

Unlike the forested catchment, the immediacy of streamflow response to rainfall as seen from the higher flashiness for the catchment under 5 years of continuous cultivation (Figure 2) suggests that part of the rainfall follows a rapid route to the stream channel, producing quickflow. In the forest, the combination of permanent soil cover, litter layer, and roots acts as a sponge soaking up water during rainy spells and releasing it more evenly than in annual cropping systems (Bruijnzeel 2004a), which corroborates our results (Figure 2a). The beneficial effects of higher organic matter contents and abundant faunal activity in forests on soil aggregate stability and water intake capacity may be retained for a year or two after clearing (Bruijnzeel 2004b). However, soil and aggregate disturbance through cultivation together with reduced litter input generally leads to a rapid decline thereafter (Lal 1987). Lal (Lal 1983) studied a 44-ha forested drainage basin on an alfisol in the humid tropical area of western Nigeria from 1979 to 1981 . He observed virtually no Hortonian overland flow and soil erosion and attributed it to the thick undergrowth and leaf litter layer. Deforestation significantly increased the total water yield by $140 \mathrm{~mm} \mathrm{yr}^{-1}$ (10\%) from 1979 to 1981 (Lal 1983).

An additional aspect in agricultural catchments is that considerable areas may become permanently occupied by compacted surfaces such as houses, yards, trails, and paths. This is almost inevitably followed by increases in amounts of runoff (Grip et al. 2004). In contrast to our study, Giertz et al. (Giertz et al. 2005) showed in subhumid, tropical Benin that continuous cropping for 100 years led to a streamwater discharge yield of $16.4 \%(190 \mathrm{~mm})$ of the rainfall per year, which was only a small increase compared to a yield of $10.2 \%(117 \mathrm{~mm})$ in the forest catchment. However, in the Benin study, both the forest and agricultural catchments were larger in size than in our experiment, about 300 ha each. Rigorous experimental designs like the "paired catchment" technique have produced detectable changes in streamflow also including large basins (Trimble et al. 1987; Bruijnzeel 1990; Malmer 1992; Fritsch 1993; Costa et al. 2003). In all cases, the removal of more than $33 \%$ of forest cover resulted in significant increases in annual streamflow during the first 3 years. Initial gains in water yield after complete forest clearance ranged between $145(9.7 \%)$ and $820 \mathrm{~mm} \mathrm{yr}^{-1}$ (32.8\%) (Bruijnzeel 1990; Malmer 1992; Fritsch 1993). In addition, increases in water yield proved to be roughly proportional to the fraction of biomass removed. These changes in water yield mainly reflect the different evaporative characteristics of mature tropical forest and (very) young secondary or planted vegetation and, to a much lesser extent, increases in storm runoff (response to rainfall). Under mature tropical rain forest, typically $80 \%-95 \%$ of incident rainfall infiltrates into the soil, of which 
Earth Interactions • Volume 16 (2012) • Paper No. 13 • Page 12

over $1000 \mathrm{~mm} \mathrm{yr}^{-1}(67 \%)$ is transpired again by the trees when soil moisture is not limiting, whereas the remainder sustains streamflow (Bruijnzeel 2004a). Chevallier and Planchon (Chevallier and Planchon 1993) found a mean annual evapotranspiration of $1600 \mathrm{~mm}$ in a 4-yr study in a 136-ha humid savannah basin in Ivory Coast.

During the dry seasons, the water discharge in the studied agricultural watersheds gradually diminished to low levels but never dried completely because of the relatively short dry season compared to the duration of the groundwater-derived baseflow recession (Figure 2). A review by Bruijnzeel (Bruijnzeel 2004b) suggests that the water holding capacity (i.e., "sponge effect") is lost after clearing, resulting in diminished dry season flows. The $42.6 \%$ increase in RR from the forest to the maize fields after 5 years of cultivation is consistent with the study by Giertz et al. (Giertz et al. 2005) in Benin. In the Benin study, RRs were 0.095 and 0.158 for the forest and agricultural catchments, respectively. In formerly forested areas in Indonesia, typical surface RR associated with bench terraced rainfed agriculture on volcanic soils in upland West Java also ranged from 0.16 to 0.18 for terraces on moderately steep slopes to greater values of $0.27-0.33$ on steep slopes (Purwanto and Bruijnzeel 1998). Our data and data from various other studies therefore indicate that conversion to agriculture causes immediate shifts in the hydrological behavior of headwater catchments.

\subsection{Effects of cultivation}

We found the overall increase in RR and storm discharge between forested and the catchment cultivated for 5 years to be similar to the increase in $R R$ and $R_{\mathrm{SF}}$ between the catchment cultivated for 5 years and the catchment cultivated for 50 years (Table 2), which may be explained by the continued and significant changes in soil properties that accompany continued cultivation. Despite the greater increase in runoff ratio per year between forest and 5 years of cultivation $\left(15 \% \mathrm{yr}^{-1}\right)$ compared to the following 45 years $\left(1 \% \mathrm{yr}^{-1}\right)$, the total change after forest clearing and during the first 5 years (43\% of total increase) or between 5 and 50 years (57\% of total increase) after forest conversion suggests long-term soil changes and their management to be important drivers of headwater hydrology in addition to changes in vegetation cover. The increase in flashiness by an average of $61 \%$ from the 5- and 10-yr-old conversions also supports this argument. The 10-yr flow duration curves (Figure 3 ) evolve toward the values of the 50-yr curve during the most common flows suggesting that baseflow is still the most dominant regime in the landscape. For the rare high flows, the 10-yr conversion matches the 5-yr conversion suggesting the possibility of compaction following cultivation.

The increase in topsoil $\rho_{b}$ from the 5- to the 50-yr-old agricultural catchment (similar to findings from a much larger set of 53 farms at the same site by Kinyangi 2008) may be an indication of changes in the soil profile that cause reduced rainfall infiltration. Similarly, Moebius-Clune et al. (Moebius-Clune et al. 2011) observed a loss of water-stable aggregates of over $90 \%$ to less than $40 \%$ on 36 farms in the same chronosequence. Several factors may contribute to loss of aggregation and reduced infiltration including continued exposure of bare soil after forest clearance to intense, high energy rainfall (Lal 1996); loss of SOC (Table 1; Solomon et al. 2007); compaction of topsoil by mechanical operations (Malmer and Grip 1990) or 
Earth Interactions - Volume 16 (2012) • Paper No. 13 • Page 13

grazing (Gilmour et al. 1987); gradual disappearance of soil faunal activity (Aina 1984); and increases in the area occupied by impervious surfaces such as paths and settlements (Ziegler and Giambelluca 1997). Increased bulk density and reduced infiltration may lead to a more pronounced catchment response to rainfall (Giertz and Diekkruger 2003) and increases in storm runoff during the rainy season may become so large as to seriously impair the recharging of the soil and groundwater reserves feedings springs and maintaining baseflow.

It is not clear, however, whether lower infiltration at the soil surface triggered the observed greater runoff, since infiltration rates may still be greater than rainfall intensities (Zimmermann et al. 2006). Often, subsurface compaction (e.g., a plow pan) may rather be responsible for overland flow through saturation excess in the surface layer. A perched water table was found to be responsible for a doubling in runoff events and a 17-fold increase in runoff volume by conversion of forest to pasture in western Amazonia (Germer et al. 2010). We are not able to distinguish between subsurface and soil surface processes that led to the observed increases in runoff in our study. It is unlikely, however, that a subsurface layer with low permeability is present in all watersheds that caused the greater proportion of runoff through a perched water table, as we would not expect greater runoff with longer duration of maize cultivation without other changes in management or plant cover. However, compaction of not only the topsoil but also the subsoil through cultivation may be a possible explanation for the observed greater runoff.

In the Benin study, Giertz et al. (Giertz et al. 2005) attributed the reduction of soil permeability after 100 or more years of cultivation to lower abundance and activity of soil organisms because of the mechanical destruction of the soil structure as well as a decrease in litterfall (Edwards and Bohlen 1996). Lower microbial activity (Kimetu et al. 2009) was also found at our sites but an explicit connection between microbial activity and soil hydrological properties has not been examined. Pedobiological investigations by Giertz et al. (Giertz et al. 2005) also demonstrated that a reduction of macrofauna activity on agricultural fields compared with natural vegetation may cause an extreme reduction of macropores at the soil surface. Reduced macroporosity is an important contributor to lower permeability of the surface in agricultural catchments. An explicit connection between macrofauna and soil permeability was not examined in our study but could well have played a role in increasing the runoff ratio.

Following 50 years of cultivation in the Kapchorwa catchments, the ability of the topsoil $(0-0.1 \mathrm{~m})$ to hold moisture at field capacity was reduced by about $34 \%$ (Table 1), similar to changes in available water capacity found by Moebius-Clune et al. (Moebius-Clune et al. 2011) for a larger set of sites in the same area. This may be attributed to losses in SOC, erosion of finer soil particles, or mechanical compaction. Soil organic C losses have been found to be significant with $67 \%-86 \%$ over 100 years following forest conversion to permanent cultivation at our study site (Solomon et al. 2007). Similar results are obtained using SOC stocks with fixed sampling depth (Nguyen et al. 2008) or with equivalent mass (Kinyangi 2008). Such SOC losses can only be compensated with organic matter amendments (Kimetu et al. 2008). Therefore, maintenance of SOC and soil biological activity, including soil macrofauna, may help reduce storm runoff and, to some extent, stream discharge in tropical headwater catchments to compensate for the loss of maintenance of a forest cover. Whether such interventions in the topsoil would 
Earth Interactions • Volume 16 (2012) • Paper No. 13 • Page 14

actually reduce discharge cannot be proven and warrants manipulative experimentation, especially if key changes occurred in the subsoil that triggered increases in runoff. In addition, maintenance of some forest cover could significantly improve flow regime as seen in a range of mixed land-use watersheds in North Carolina (Price et al. 2011).

\section{Conclusions}

The increase of surface runoff as a result of the loss of forest cover was similar in magnitude as increases observed corresponding to long-term cultivation. This would suggest that preservation of forest cover is only one avenue for decreasing storm water runoff and discharge from headwaters. Equally important may be the maintenance of infiltration and water retention in soil, but it is not clear to what extent subsurface changes contributed to the observed runoff responses. Further experimentation is required to evaluate whether discharge and runoff can be reduced by SOC buildup, reduced compaction of surfaces or plough pans, or less sealing of surfaces. This would have important implications for policy interventions to promote soil conservation techniques such as no tillage, mulching, crop rotations, or intercropping. Questions arise whether nutrient and SOC losses follow the same trends as water discharge shown here. In addition, soil management that maintains water retention and decreases runoff and discharge warrant evaluation on a watershed scale.

Acknowledgments. The authors thank Brett Gleitsmann for assistance in identifying the study sites, constructing the weirs, and doing initial sampling. We thank Henry Biwott for help with field work. This research was financially supported in part by grants from the Ford Foundation International Fellowships Program, the National Science Foundation Grant 0215890 through CIIFAD, the Biogeochemistry and Environmental Biocomplexity Small Grant Program Ref. DGE 0221658, Towards Sustainability Fund, the Institute for African Development, and the Norman Borlaug Leadership Enhancement in Agriculture Program Fellowship. Logistical support was provided by the World Agroforestry Centre Kisumu office. We thank the anonymous referees for their valuable suggestions.

\section{References}

Aina, P. O., 1984: Contribution of earthworms to porosity and water infiltration in a tropical soil under forest and long-term cultivation. Pedobiologia, 26, 131-136.

Awiti, A. O., M. G. Walsh, and J. Kinyamario, 2008: Dynamics of topsoil carbon and nitrogen along a tropical forest-cropland chronosequence: Evidence from stable isotope analysis and spectroscopy. Agric. Ecosyst. Environ., 127, 265-272.

Baker, D. B., P. Richards, T. T. Loftus, and J. W. Kramer, 2004: A new flashiness index: Characteristics and applications to Midwestern rivers and streams. J. Amer. Water Resour. Assoc., 40, 503-522.

Berger, K. P., and D. Entekhabi, 2001: Basin hydrologic response relations to distributed physiographic descriptors and climate. J. Hydrol., 247, 169-182.

Bleher, B., D. Uster, and T. Bergsdorf, 2006: Assessment of threat status and management effectiveness in Kakamega forest, Kenya. Biodiversity Conserv., 15, 1159-1177.

Bloomfield, J. P., D. J. Allen, and K. J. Griffiths, 2009: Examining geological controls on baseflow index (BFI) using regression analysis: An illustration from the Thames Basin, UK. J. Hydrol., 373, 164-176. 
Earth Interactions - Volume 16 (2012) • Paper No. 13 • Page 15

Bonell, M., and J. Balek, 1993: Recent scientific developments and research needs in hydrological processes of the humid tropics. Hydrology and Water Management in the Humid Tropics, M. Bonell, M. Hufschmidt, and J. S. Gladwell, Eds., Cambridge University Press, 167-260.

Bosch, J. M., and J. D. Hewlett, 1982: A review of catchment experiments to determine the effect of vegetation changes on water yield and evapotranspiration. J. Hydrol., 55, 3-23.

Bruijnzeel, L. A., 1990: Hydrology of Moist Tropical Forest and Effects of Conversion: A State of Knowledge Review. UNESCO, 224 pp.

_ 2004a: Hydrological functions of tropical forests: Not seeing the soil for the trees? Agric. Ecosyst. Environ., 104, 185-228.

— 2004b: Tropical montane cloud forest: A unique hydrological case. Forests, Water, and People in the Humid Tropics: Past, Present and Future Hydrological Research for Integrated Land and Water Management, M. Bonell, and L. A. Bruijnzeel, Eds., Cambridge University Press, 462-483.

Calder, I. R., 1998: Water use by forests, limits and controls. Tree Physiol., 18, 625-631.

Campbell, D. J., and J. K. Henshall, 1991: Bulk density. Soil Analysis: Physical Methods, K. A. Smith and C. E. Mullins, Eds., Marcel Dekker, 329-366.

Chevallier, P., and O. Planchon, 1993: Hydrological processes in a small humid savanna basin. J. Hydrol., 151, 173-191.

Costa, M. H., A. Botta, and J. A. Cardille, 2003: Effects of large-scale changes in land cover on the discharge of the Tocantins River, Amazonia. J. Hydrol., 283, 206-217.

deGraffenried, J. B., Jr., and K. D. Shepherd, 2009: Rapid erosion modeling in a western Kenya watershed using near infrared reflectance, classification tree analysis and ${ }^{137} \mathrm{Cesium}$. Geoderma, 154, 93-100, doi:10.1016/j.geoderma.2009.10.001.

Edwards, C. A., and P. J. Bohlen, 1996: Biology and Ecology of Earthworms. Chapman and Hall, $438 \mathrm{pp}$.

Eeles, C. W., 1979: Soil moisture deficits under montane rain forest and tea. East Afr. Agric. For. J., 43, 128-138.

Elsenbeer, H., 2001: Hydrologic flowpaths in tropical rainforest soilscapes-A review. Hydrol. Processes, 15, 1751-1759.

FAO, cited 2010: Global forest resources assessment 2005. Food and Agriculture Organization of the United Nations. [Available online at http://www.fao.org/forestry/site/countryinfo/en/ken.]

FAO-UNESCO-ISRIC, 1988: Revised legend, FAO-UNESCO soil map of the world. World Soil Resources Rep. 60, 109 pp.

Farley, K. A., E. G. Jobbagy, and R. B. Jackson, 2005: Effects of afforestation on water yield: A global synthesis with implications for policy. Global Change Biol., 11, 1565-1576.

Fritsch, J. M., 1993: The hydrological effects of clearing tropical rain forest and of the implementation of alternative land uses. Hydrology of warm humid region, International Association of Hydrological Sciences Publication 216, 53-66.

Germer, S., H. Elsenbeer, and J. M. Moraes, 2006: Throughfall and temporal trends of rainfall redistribution in an open tropical rainforest, south-western Amazonia (Rondônia, Brazil). Hydrol. Earth Syst. Sci., 10, 383-393.

_ C. Neill, A. V. Krusche, and H. Elsenbeer, 2010: Influence of land use change on near surface hydrological processes: Undisturbed forest to pasture. J. Hydrol., 380, 473-480.

Giertz, S., and B. Diekkruger, 2003: Analysis of the hydrological processes in a small headwater catchment in Benin (West Africa). Phys. Chem. Earth, 28, 1333-1341.

_ - B. Junge, and B. Diekkruger, 2005: Assessing the effects of land use change on soil physical properties and hydrological processes in the sub-humid tropical environment of West Africa. Phys. Chem. Earth, 30, 485-496.

Gilmour, D. A., M. Bonell, and D. S. Cassells, 1987: The effects of forestation on soil hydraulic properties in the Middle Hills of Nepal: A preliminary assessment. Mt. Res. Dev., 7, 239-249.

Glenday, J., 2006: Carbon storage and emissions offset potential in an East African tropical rainforest. For. Ecol. Manage., 235, 72-83. 
Earth Interactions - Volume 16 (2012) • Paper No. 13 • Page 16

Grip, H., J. M. Fritsch, and L. A. Bruijnzeel, 2004: Soil and water impacts during forest conversion and stabilization to new land use. Forests, Water, and People in the Humid Tropics: Past, Present and Future Hydrological Research for Integrated Land and Water Management, M. Bonell and L. A. Bruijnzeel, Eds., Cambridge University Press, 561-589.

Hartemink, A. E., T. Veldkamp, and Z. G. Bai, 2008: Land cover change and soil fertility decline in tropical regions. Turk. J. Agric. For., 32, 195-213.

Haupt, M., 2000: Traditional Use of and Reliance on the Forest Among the Luhya People with Special Regard to the Traditional Medical System and Use of Medicinal Plants in Kakamega Forest, Western Kenya. Materialien zur Ostafrika-Forschung, Vol. 24, Geographische Gesellschaft Trier, 129 pp.

Hertel, D., G. Moser, H. Culmsee, S. Erasmi, V. Horna, B. Schuldt, and C. Leuschner, 2009: Below and above ground biomass and net primary production in a paleotropical natural forest (Sulawesi, Indonesia) as compared to neotropical forest. For. Ecol. Manage., 258, 1904-1912.

Huggett, R. J., 1998: Soil chronosequences, soil development, and soil evolution: A critical review. Catena, 32, 155-172.

Jätzold, R., and H. Schmidt, 1983: Natural Conditions and Farm Management Information, Part A: West Kenya. Vol. 2, Farm Management Handbook of Kenya, Kenya Ministry of Agriculture and Livestock Development, 319 pp.

Johnson, M. S., J. Lehmann, E. G. Couto, J. P. Novaes-Filho, and S. Riha, 2006: DOC and DIC in flowpaths of Amazonian headwater catchments with hydrologically contrasting soils. Biogeochemistry, 81, 45-57.

Kenya Forest Service, 2007: Forest law enforcement and governance in Kenya. Kenya Forest Service Rep., 64 pp.

Kimetu, J. M., and Coauthors, 2008: Reversibility of soil productivity decline with organic matter of differing quality along a degradation gradient. Ecosystems, 11, 726-739.

—, J. Lehmann, J. M. Kinyangi, C. H. Cheng, J. Thies, D. N. Mugendi, and A. Pell, 2009: Soil organic C stabilization and thresholds in C saturation. Soil Biol. Biochem., 41, 2100-2104.

Kinyangi, J. M., 2008: Soil degradation, thresholds and dynamics of long-term cultivation: From landscape biogeochemistry to nanoscale biogeocomplexity. Ph.D. dissertation, Cornell University, $158 \mathrm{pp}$.

Klute, A., 1986: Water retention: Laboratory methods. Methods of Soil Analysis Part 1, Agronomy Monogr., No. 9, ASA and SSSA, 635-662.

Lal, R., 1981: Deforestation of tropical rainforest and hydrological problems. Tropical Agricultural Hydrology, R. Lal, and E. W. Russell, Eds., Wiley, 131-140.

_ 1983: Soil erosion in the humid tropics with particular reference to agricultural land development and soil management. Hydrology of Humid Tropical Regions with Particular Reference to the Hydrological Effects of Agriculture and Forestry Practice, R. Keller, Ed., International Association of Hydrological Sciences, 221-239.

— 1987: Tropical Ecology and Physical Edaphology. Wiley and Sons, 732 pp.

_ 1996: Deforestation and land-use effects on soil degradation and rehabilitation in western Nigeria. I. Soil physical and hydrological properties. Land Degrad. Dev., 7, 19-46.

Lilienfein, J., and W. Wilcke, 2004: Water and element input into native, agri- and silvicultural ecosystems of the Brazilian savanna. Biogeochemistry, 67, 183-212.

Lim, K. J., B. A. Engel, Z. Tang, J. Choi, K. Kim, S. Muthukrishnan, and D. Tripathy, 2005: Automated Web GIS based Hydrograph Analysis Tool, WHAT. J. Amer. Water Resour. Assoc., 41, 1407-1416, doi:10.1111/j.1752-1688.2005.tb03808.x.

— , Y. S. Park, J. Kim, Y. Shin, N. W. Kim, S. J. Kim, J. Jeon, and B. A. Engel, 2010: Development of genetic algorithm-based optimization module in WHAT system for hydrograph analysis and model application. Comput. Geosci., 36, 936-944, doi:10.1016/j.cageo.2010.01.004.

Longobardi, A., and P. Villani, 2008: Baseflow index regionalization analysis in a Mediterranean area and data scarcity context: Role of catchment permeability index. J. Hydrol., 355, 63-75, doi:10.1016/j.jhydrol.2008.03.011. 


\section{Earth Interactions - Volume 16 (2012) • Paper No. 13 • Page 17}

Low, K. S., and K. C. Goh, 1972: Water balance studies in Selangor, west Malaysia. Trop. Geogr., 35, 60-66.

Lung, T., and G. Schaab, 2006: Assessing fragmentation and disturbance of west Kenyan rainforests by means of remotely sensed time series data and landscape metrics. Afr. J. Ecol., 44, 491-506.

Malmer, A., 1992: Water yield changes after clear-felling tropical rainforest and establishment of forest plantation in Sabah, Malaysia. J. Hydrol., 134, 77-94.

— manual extraction of tropical rainforest in Sabah, Malaysia. For. Ecol. Manage., 38, 1-12.

Mitchell, N., 2004: The Exploitation and Disturbance History of Kakamega Forest, Western Kenya. Vol. 20, Bielefelder Ökologische Beiträge, Abteilung Okologie der Universitat Bielefeld, $77 \mathrm{pp}$.

Moebius-Clune, B. N., H. M. van Es, O. J. Idowu, R. R. Schindelbeck, J. M. Kimetu, S. Ngoze, J. Lehmann, and J. M. Kinyangi, 2011: Long-term soil quality degradation along a cultivation chronosequence in western Kenya. Agric. Ecosyst. Environ., 141, 86-99.

Muller, D., and J. Mburu, 2009: Forecasting hotspots of forest clearing in Kakamega Forest, western Kenya. For. Ecol. Manage., 257, 968-977.

Mumeka, A., 1986: Effect of deforestation and subsistence agriculture on runoff of the Kafue river headwaters, Zambia. Hydrol. Sci. J., 31, 543-554.

Nepstad, D. C., and Coauthors, 1994: The role of deep roots in the hydrological and carbon cycles of Amazonian forests and pastures. Nature, 372, 666-669.

Ngoze, S. O., S. Riha, J. Lehmann, L. Verchot, J. Kinyangi, D. Mbugua, and A. Pell, 2008: Nutrient constraints to tropical productivity in long-term degrading soils. Global Change Biol., 14, 2810-2822, doi:10.1111/j.1365-2486.2008.01698.x.

Nguyen, B., J. Lehmann, J. Kinyangi, R. Smernik, S. J. Riha, and M. H. Engelhard, 2008: Longterm black carbon dynamics in cultivated soil. Biogeochemistry, 89, 295-308.

Price, K., C. R. Jackson, and A. J. Parker, 2010: Variation of surficial soil hydraulic properties across land uses in the southern Blue Ridge Mountains. J. Hydrol., 383, 256-268.

,,,--- T. Reitan, J. Dowd, and M. Cyterski, 2011: Effects of watershed land use and geomorphology on stream low flows during severe drought conditions in the southern Blue Ridge Mountains, Georgia and North Carolina, United States. Water Resour. Res., 47, W02516, doi:10.1029/2010WR009340.

Purwanto, E., and L. A. Bruijnzeel, 1998: Soil conservation on rainfed bench terraces in upland west Java, Indonesia: Towards a new paradigm. Adv. Geoecol., 31, 1267-1274.

Ruprecht, J. K., and N. J. Schofield, 1989: Analysis of streamflow generation following deforestation in southwest Western Australia. J. Hydrol., 105, 1-17.

Schwartz, S. S., 2007: Automated algorithms for heuristic base-flow separation. J. Amer. Water Resour. Assoc., 43, 1583-1594, doi:10.1111/j.1752-1688.2007.00130.x.

Solomon, D., and Coauthors, 2007: Long-term impacts of anthropogenic perturbations on dynamics and speciation of organic carbon in tropical forest and subtropical grassland ecosystems. Global Change Biol., 13, 511-530.

— and molecular-level speciation of soil sulfur. Ecol. Appl., 19, 989-1002.

Spaans, E. J. A., G. A. M. Baltissen, J. Bouma, R. Miedeme, A. L. E. Lansu, D. Schoonderbeek, and W. G. Wielemaker, 1989: Changes in physical properties of young and old volcanic surface soils in Costa Rica after clearing of tropical rain forest. Hydrol. Processes, 3, 383-392.

Storer, D. A., 1984: A simple high sample volume ashing procedure for determination of soil organic matter. Commun. Soil Sci. Plant Anal., 15, 759-772.

Swallow, B. M., J. K. Sang, M. Nyabenge, D. K. Bundotich, A. K. Duraiappah, and T. B. Yatich, 2009: Tradeoffs, synergies and traps among ecosystem services in the Lake Victoria basin of East Africa. Environ. Sci. Policy, 12, 504-519, doi:10.1016/j.envsci.2008.11.003. 
Earth Interactions - Volume 16 (2012) • Paper No. 13 • Page 18

Trimble, S. W., F. H. Weirich, and B. L. Hoag, 1987: Reforestation and the reduction of water yield on the southern Piedmont since circa 1940. Water Resour. Res., 23, 425-437.

U.S. Natural Resources Conservation Service, 2003: Keys to Soil Taxonomy. 9th ed. U.S. Department of Agriculture Natural Resources Conservation Service, 332 pp.

Van Dijk, A. I. J. M., and L. A. Bruijnzeel, 2001: Modelling rainfall interception by vegetation of variable density using an adapted analytical model. Part 2. Model validation for a tropical upland mixed cropping system. J. Hydrol., 247, 239-262.

Vogel, R. M., and N. M. Fennessey, 1994: Flow-duration curves I: New interpretation and confidence intervals. J. Water Resour. Plan. Manage., 120, 485-502.

Werner, C., R. Kiese, and K. Butterbach-Bahl, 2007: Soil-atmosphere exchange of $\mathrm{N}_{2} \mathrm{O}, \mathrm{CH}_{4}$, and $\mathrm{CO}_{2}$ and controlling environmental factors for tropical rain forest sites in western Kenya. J. Geophys. Res., 112, D03308, doi:10.1029/2006JD007388.

World Bank, 2008: Kenya poverty and inequality assessment: Volume I. World Bank Synthesis Rep. 44190-KE, 196 pp.

Ziegler, A. D., and T. W. Giambelluca, 1997: Importance of rural roads as source areas for runoff in mountainous areas of northern Thailand. J. Hydrol., 196, 204-229.

Zimmermann, B., H. Elsenbeer, and J. M. De Moraes, 2006: The influence of land-use changes on soil hydraulic properties: Implications for runoff generation. For. Ecol. Manage., 222, 29-38.

Earth Interactions is published jointly by the American Meteorological Society, the American Geophysical Union, and the Association of American Geographers. Permission to use figures, tables, and brief excerpts from this journal in scientific and educational works is hereby granted provided that the source is acknowledged. Any use of material in this journal that is determined to be "fair use" under Section 107 or that satisfies the conditions specified in Section 108 of the U.S. Copyright Law (17 USC, as revised by P.IL. 94553) does not require the publishers' permission. For permission for any other from of copying, contact one of the copublishing societies. 